\title{
The Different Chemical Reaction Model Analysis in Combustion Chamber
}

\author{
Y.Z .Zhang, Z. Li \\ Faculty of science in Inner Mongolia university of technology \\ Hohhot inner Mongolia China
}

\begin{abstract}
Effective mixing and rapid combustion is very important to the flow field of combustion chamber in solid rocket ramjet. The flow field of combustion chamber in solid rocket ramjet was simulated based on finite rate chemical reaction model and infinite rate chemical reaction model .The result of two kinds of chemical reaction model compared with the experimental result. The result shows that the two kinds of chemical reaction model are feasible, and the calculated result is reasonable.
\end{abstract}

Keywords-solid rocket ramjet; combustion chamber; numerical simulation; chemical reaction model

\section{INTRODUCTION}

Solid rocket ramjet can work normally under complex environment that is a key problem in engine development. More additions which like aluminum and magnesium metal components were currently used in solid rocket ramjet propellant. With the metal content increasing in the propellant, combustion products will contain a large amount of unburned completely particles from the combustion chamber. The heat influences in flow field was determined by whether particles was fully mixed and completely burned with air or not. Therefore gas mixture combustion with particles was analyzed on different reaction rate of chemical reaction model.

Research on chemical reaction rate model, there have been many studies reported ${ }^{[1-6]}$, In this article, infinite and finite rate chemical reaction model which 20 components and 23 reaction was used in the process of combustion. The flow field which contains three kinds of condensed particle was simulated in combustion chamber of solid rocket ramjet. On the basis of the above discussion, the relate parameters of combustion in solid rocket ramjet was analyzed.

\section{PHYSICAL MODEL AND BOUNDARY CONDITIONS}

\section{A. Physical Model}

Content of oxygen was $23 \%$ that in the oxidant propellant was used in gas generator. The burning gas fill into the combustion chamber is rich. Air through four $45^{\circ}$ inlet into the combustion chamber was reacted with fuel gas. The form of nozzle was single nozzle in the gas generator, the physical model that in this paper numerical simulation of solid rocket ramjet was shown in figure 1 . It take $1 / 4$ part of the structure as a model to calculate because the structure is symmetrical in this paper.

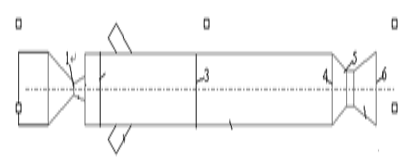

FIGURE I. STRUCTURE GRAPH IN THE COMBUSTION CHAMBER OF SOLID ROCKET RAMJET.

Calculation of the boundary condition is determined according to the real working state of the engine. The simulation of engine work status to: under a certain altitude, the air in the inlet through three oblique shock wave and a normal shock into the combustion chamber. The inlet and outlet boundary conditions as follows: total temperature was $573 \mathrm{k}$ in air inlet; The air flow was $0.3685 \mathrm{~kg} / \mathrm{s}$ in every air inlet. Gas flow according to the air-fuel ratio of 12.6 . The gas flow was $0.117 \mathrm{~kg} / \mathrm{s}$, total gas temperature was $1850 \mathrm{k}$. Aluminized propellant was chosen as the gas generator propellant, gas components of lean oxygen were calculated by thermodynamic calculation program, and mass fraction of the components is more than $1 \%$ as gas entrance components in combustion chamber.

\section{CHEMICAL REACTION MODEL}

\section{A. Finite Rate Reaction Model}

Solid rocket ramjet gas is composed of multiple components, which in the process of flow with chemical reaction between components. Aluminized composite propellant gas composition was very complicated, including more than 40 kinds of components, need to spend a lot of time on the solution. For simplicity, 20 kinds of main components were calculated such as $\mathrm{H}, \mathrm{O}, \mathrm{OH}, \mathrm{H}_{2}$, $\mathrm{H}_{2} \mathrm{O}, \mathrm{CO}_{2}, \mathrm{CO}, \mathrm{N}, \mathrm{N}_{2}, \mathrm{Cl}, \mathrm{Al}, \mathrm{AlCl}, \mathrm{AlCl}_{2}, \mathrm{AlO}, \mathrm{AlOCl}, \mathrm{AlOH}, \mathrm{HCl}$. Main components and chemical reaction model are listed below:

$$
\begin{gathered}
\mathrm{H}+\mathrm{H}+\mathrm{M} \Leftrightarrow \mathrm{H}_{2}+\mathrm{M}, \mathrm{H}+\mathrm{OH}+\mathrm{M} \Leftrightarrow \mathrm{H}_{2} \mathrm{O}+\mathrm{M}, \\
\mathrm{CO}+\mathrm{O}+\mathrm{M} \Leftrightarrow \mathrm{CO}_{2}+\mathrm{M}, \mathrm{AlCl}+\mathrm{Cl}+\mathrm{M} \Leftrightarrow \mathrm{AlCl}_{2}+\mathrm{M}, \\
\mathrm{CO}+\mathrm{OH} \Leftrightarrow \mathrm{CO}_{2}+\mathrm{H}, \mathrm{HCl}+\mathrm{OH} \Leftrightarrow \mathrm{H}_{2} \mathrm{O}+\mathrm{Cl}, \\
\mathrm{Al}+\mathrm{HCl} \Leftrightarrow \mathrm{AlCl}+\mathrm{H}, \quad \mathrm{Al} \mathrm{O}+\mathrm{HCl} \Leftrightarrow \mathrm{AlOCl}+\mathrm{H}, \\
\mathrm{AlCl}+\mathrm{OH} \Leftrightarrow \mathrm{AlOCl}+\mathrm{H}, \mathrm{AlCl}+\mathrm{H} \Leftrightarrow \mathrm{AlCl}+\mathrm{HCl}, \\
\mathrm{N}_{2}+\mathrm{M} \Leftrightarrow \mathrm{N}+\mathrm{N}+\mathrm{Ml}+\mathrm{O}_{2}=>\mathrm{Al} \mathrm{O}, \mathrm{AlO}+\mathrm{O}_{2}=> \\
\mathrm{AlO}_{2}+\mathrm{O}, \\
\mathrm{Al}+\mathrm{CO}_{2}=>\mathrm{AlO}+\mathrm{CO}, \mathrm{Al}+\mathrm{H}_{2} \mathrm{O}=>\mathrm{AlO}+\mathrm{H}_{2} \\
2 \mathrm{Mg}+\mathrm{O}_{2}=>2 \mathrm{MgO}, \quad \mathrm{Mg}+\mathrm{CO}_{2}=>\mathrm{MgO}+\mathrm{CO},
\end{gathered}
$$


$\mathrm{Mg}+\mathrm{H}_{2} \mathrm{O}=>\mathrm{MgO}+\mathrm{H}_{2}, \mathrm{Mg}+\mathrm{HCl} \Leftrightarrow \mathrm{MgCl}+\mathrm{H}$,

$$
\mathrm{M} \gamma \mathrm{O}+\mathrm{HX} \lambda<=>\mathrm{M} \gamma \mathrm{OX} \lambda+\mathrm{H}
$$

\section{B. Infinite Rate Reaction Model (PDF Model)}

Infinite rate reaction model is non premixed combustion model, which is suitable for the fuel and oxidant respectively from different entrance. That is to say, fuel and oxidant is not mixture before burning, so it is called "non premixed". Finite rate chemical reaction model is not used in non premixed combustion calculation, but using the probability density function (PDF) to solute unknown variables which the uniform mixture concentration can be obtained. The source term which generated or disappear was not calculated in the calculation.

\section{PARTICles COMBUSTION MODEL}

Due to the low melting point and boiling point of magnesium, magnesium as gas to deal with in theory into the combustion chamber. Therefore only consider aluminum particles and carbon particles in the combustion chamber. So particle combustion droplet evaporation model was adopted ${ }^{[7-9]}$ When the mass and heat exchange between particles and the continuous phase, the mass transfer equation was:

$$
m_{p} c_{p} \frac{d T_{p}}{d t}=h A_{p}\left(T_{\infty}-T_{p}\right)+\frac{d m_{p}}{d t} h_{f g}+A_{p} \varepsilon_{p}\left(\theta_{R}^{4}-T_{p}^{4}\right)
$$

\section{The Results OF SimUlation AND ANALYSIS}

\section{A. Flow Field}

Flow field is very complex in combusion chamber, as shown in figure 2 . The results was calculated both Infinite and finite rate reaction model which there were eddies in the whole flow field in combusion chamber. Eddies which in the upper, due to the air ejector effect, fluid of collision with cylindrical vessel wall, near the wall to formed a spiral1, along with the development of the downstream, spiral was gradually disappear. supersonic gas from the nozzle collided with air of head and gases mixed in combusion chamber. Part of the flow of gas and air friction, forming a large spiral 2; Another part of the flowing gas and gas friction mixing, forming a range narrow spiral 3 .

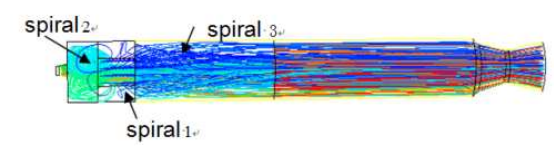

FIGURE II. FLOW LINE IN COMBUSTION CHAMBER OF SOLID ROCKET RAMJET

\section{B. Result Comparison between Infinite Rate Model and the Finite Rate Model}

The trend can be seen from the figure 3 .Under the infinite reaction rate of the mass fraction of $\mathrm{H} 2 \mathrm{O}$ was higher than finite rate reaction. Because of finite rate reaction was more close to reality, inadequate to reaction .So it may be due to mass fraction was low.

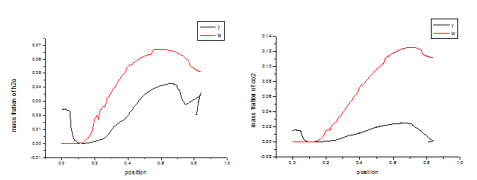

FIGURE III. THE MASS FRACTION OF H2O AND CO2 ON THE TWO RATE REACTION

Exit parameters table can be seen in table 1. The pressure temperature speed of Infinite rate model were higher than finite rate model, because chemical reaction was not sufficient in the finite rate chemical reaction model, and it didn't full combusted. So it lead to reduces specific impulse of solid rocket ramjet, we should adopted chemical reaction equation and mechanism which more reasonable and detail.

TABLE I .EXIT PARAMETERS VALUE TABLE.

\begin{tabular}{|l|l|l|l|l|}
\hline Exit & $\begin{array}{l}\text { pressure } \\
\text { (pa) }\end{array}$ & $\mathbf{V}(\mathbf{m} / \mathbf{s})$ & $\begin{array}{c}\text { temperature } \\
(\mathbf{k})\end{array}$ & $\begin{array}{l}\text { specific } \\
\text { impulse } \\
\text { (N.S/kg) }\end{array}$ \\
\hline $\begin{array}{l}\text { Infinite } \\
\text { rate }\end{array}$ & 70551 & 1227.77 & 1718.427 & 7158.3 \\
\hline $\begin{array}{l}\text { finite } \\
\text { rate }\end{array}$ & 55672 & 1145.59 & 1645.321 & 6444.4 \\
\hline
\end{tabular}

\section{CONCLUSION}

(1) Flow field is very complex, there were some vortex in the combustion chamber .

(2) Compared with infinite rate reaction model, found that the basic flow field performance are the same, but the infinite rate model of the pressure, temperature, more higher than finite rate model, it may be that the finite rate under the condition of chemical reaction was not sufficient, didn't get the full combustion.

\section{REFERENCES}

[1] David A P, Kenneth E E. Phase transformations in metals and alloys[ M] . New York: Van Nostrand Reinhold Company,1981.

[2] Perepezko J P. Solidification of highly undercooled liquid metals and alloys[ R] . AIAA-1979-0030, 1979.

[3] Lee E S ,Ahn S . Solidification process and heat transfer analysis of gasaplets during spray forming[J].Act a Metallurgicaet Materialia, 1994, 42( 9 ) : :3231-3243.

[4] Liu Dongming, Zhao Jiuzhou, Ye Hengqiang. Modeling of the solidification of gas-atomized alloy droplets during spray forming $[\mathrm{J}]$. Act a Metallurgica, 2003, 39(4): 375-380. (in Chinese)

[5] Guan Wanbing, Gao Yulai, Zhai Qi jie, et al. DSC study of solidification subcooling of metal melt micro-drople[J].Chinese Science Bullet in , 2005( 11): 1142-1144. (in Chinese)

[6] Jian Zengyun, Chang Fange, Ma Weihong, etal. Nucleation and subcooling of molten metal [J] . Science in China, 2000, 30(1): 9-14. (in Chinese)

[7] Zhao Jiuzhou, Liu Dongming, Wang Jiangtao, etal . Simulation of spray forming [J] . Special Casting \& Nonferrous Alloys, 2004(4) : 1- 3. (in Chinese)

[8] Liang Hongyu, Mao Xiemin , Hu Zhihen g. Modeling of cooling and solidification process of the atomized $\mathrm{Al}-\mathrm{Si}$ alloy droplets $[\mathrm{J}]$. Foundry Technology, 2007, 28(3): 367-372. (in Chinese)

[9] Huo Guang, Xie Ming, Chen Li, etal. The mathematical model and analysis of alloy droplet during atomization solidification [J] . Metal Forming Technology, 2003, 21(6):103-105. (in Chinese) 